\title{
RE-CONCEPTUALISING \\ LEADERSHIP FOR EFFECTIVE \\ PEACEMAKING AND HUMAN \\ SECURITY IN AFRICA
}

\author{
'Funmi Olonisakin \\ African Leadership Centre \\ King's College London, United Kingdom \\ and Department of Political Sciences \\ University of Pretoria, South Africa
}

\section{Abstract}

This article explores the meaning of peace and human security from the perspective of the individual - the presumed referent point of security - and examines responses to armed conflict, a leading source of insecurity for African peoples. It identifies inherent flaws in approaches to conflict in Africa and looks to a different field - that of leadership for a more effective formula for peacemaking. In the absence of a framework that can effectively end the cycle of conflict relapse in Africa, the paper argues that an alternative framing of leadership is needed; and that alternative leadership approaches to dealing with conflict and insecurity offer a chance for stable peace and human security. It suggests that an expanded perspective on leadership provides a basis for exploring interventions that can potentially alter peacemaking discourses as well as the terrain in which peacemaking takes place. The article therefore asks what a focus on the individual as the referent point of security means if and when viewed from the perspective of a collection of individuals. In this regard, it presents emerging perspectives from a study of young Africans on leadership programmes in a classroom setting and attempts to extrapolate them to wider societal settings. It then explores how a different perspective of leadership might serve as a facilitator of peace and human security in Africa, drawing examples 
from past and on-going situations of armed conflict in Africa.

\section{Introduction}

Defining what constitutes peace is as elusive as finding a sustainable threshold within which human communities can live in harmony, while also seeking to attain their full potential. This notwithstanding, the failure of peace in society is often self-evident. Johan Galtung's time-honoured notion of peace is of something more than just the absence of war, which has since become widely known as negative peace. Rather, he advanced the notion of positive peace, which he first described as the "integration of human society" (Galtung 1964:2). Building on this, positive peace also came to be seen as the absence of structural violence (Galtung 1969). Direct and structural violence are rooted in the structure of society and the social justice issues contained therein. As such, given the underlying justice issues, the connections between peace and security are not farfetched. Arguably, then, the prevention of both direct and structural violence would create conditions for peace as well as security.

The elusiveness of peace remains a recurring feature in conflict situations at all levels of society in Africa. This is evident in the diversity of conflict situations on the continent. This can be seen, for example, in the mutations of civil conflict in the Democratic Republic of Congo (DRC); grievances that linger in the memory of victims of violence in Zimbabwe; non-state conflicts that result from competing approaches to the pursuit of wellbeing among communities; and in the terror visited upon populations by insurgent groups like Al-Shabaab and Boko Haram with unconventional demands on state actors. ${ }^{1)}$ Finding that stable threshold of harmonious relations within which people can pursue their individual and collective aspirations is the challenge that lies at the heart of much conflict in Africa and elsewhere.

Indeed, violent conflict remains perhaps the single most intractable challenge to human security in Africa. It is estimated that the continent has lost about 12 million people to civil war since 1991. As Rotberg notes, "on no other continent has so many lives been lost to civil war" (Rotberg 2007: 17). There is a realisation globally, that conflict is not abating. Rather, it is constantly mutating or relapsing periodically. Available evidence suggests that the relapse of armed conflict poses a difficult challenge for regional and global actors alike. It is estimated, for 
example, that 42 per cent of armed conflicts that resulted in negotiated settlements between 1945 and 2004 relapsed (Lacina and Gleditsch 2005). The persistent challenge of relapse accounts in part, for the United Nations (UN) General Assembly and Security Council's effort to undertake a comprehensive review of the UN Peacebuilding Architecture in 2015.

The perpetual insecurities encountered in the search for stable peace make the notion of human security particularly relevant in Africa. Earlier contestation about the intellectual usefulness of this notion (Buzan et al 1998; Paris 2001) is now less emphasised even if it remains unresolved. It is difficult to challenge the idea that the wellbeing of individuals must be central to considerations of security in the face of the extreme violence and humanitarian tragedies witnessed in Africa in the past two decades. African regional and continental institutions have embraced the human security agenda at least in principle. As such, there is an acceptance that it should be possible to pierce the veil of sovereignty in order to respond to untold human suffering and largescale insecurities within states. This is exemplified by the $A U$ Constitutive Act (Article 4h) which opened the door to the possibility of interventions in situations of human tragedies.

However, more than two decades after visible commitment to the idea of human security and implicit acceptance that the wellbeing of individuals should matter more in security considerations, Africa does not have sustainable peace. Attempts to realise this through democratisation have not given way to democratic consolidation. Extant policy and normative frameworks at regional and continental levels are yet to deliver stable peace and sustainable development despite sound articulation. The African Peace and Security Architecture (APSA) and the ECOWAS Conflict Prevention Framework (ECPF) are cases in point. The threat landscape is rapidly evolving and the mutation of old conflicts into new forms of threats makes it difficult to challenge any attempt to explore alternative ideas for achieving stable peace and security in Africa.

This article looks for answers in a realm, that is ubiquitous, but underutilised and under-explored in peace and security situations that of leadership. It argues that an alternative framing of leadership and alternative leadership approaches to conflict and insecurity offer a chance for stable peace and sustainable development. If other approaches have yet to deliver stable peace for Africa, it is worth exploring 
ideas that offer promise. As such this article addresses itself to two sets of inter-related questions. First, to what extent do peacemaking efforts focus on the perspectives of individuals in conflict affected societies? Whose ideas of peace underpin peacemaking efforts - those of feuding elites or affected populations? What role does leadership play in shaping the outcomes of peacemaking efforts and how might a different perspective of leadership contribute to sustaining peace and thus enhancing human security?

The article is organised in five parts. Section two, which follows this introductory section, establishes a conceptual and theoretical framework. The third section examines individual perspectives of peace and security. In this regard, it presents emerging perspectives from exploratory research. It provides key highlights from a study of young Africans on leadership programmes in a classroom setting and attempts to extrapolate this to wider societal settings. Section four focuses on a particular dimension of leadership — process-based leadership. It explores how this perspective of leadership might serve as a facilitator of peace and human security in Africa, drawing from experiences in several situations of conflict and insecurity. Section five offers a conclusion to this article.

\section{Establishing a conceptual and theoretical framework}

The notion of peace and security from the perspective of the individual is little explored. Indeed, with few exceptions including Galtung's seminal work mentioned in the first section of this article, peace is little conceptualised. Nonetheless, since human security highlights the individual as an important referent object, there is a basis to take a view from below. This article takes the notion of security from the perspective of individuals further by seeking to cumulate views from below.

\subsection{Taking security complex theory to the individual level}

The frontiers of security discourse have been significantly expanded by the work of Buzan and others (1998), which examines threats to refer- 
ent objects beyond the earlier exclusive focus on the state and on largely military threats that had characterised the Cold War. By widening security beyond a focus on the state, it is thus possible to look at levels below the state including 'sub-units', that is, sub-state or "organised groups of individuals", and at individuals, which Buzan et al (1998: 5) refer to as "the bottom-line of most analysis in the social sciences". The possibility of focusing on sectors other than the military allowed for a focus on sub-state and the door was left wide open for an in-depth examination of the level of individuals.

A particularly relevant aspect of Buzan's security analysis from the perspective of this article is the security complex theory (Buzan 1983), which focuses on the idea of 'security regions'. Buzan, Waevar and de Wilde (1998) defined a security complex as "a set of states, whose major security perceptions and concerns are so interlinked that their national security problems cannot reasonably be analysed or resolved apart from one another" (Buzan et al 1998:12). The wider security agenda sought to move classical security complex theory beyond the idea of security regions since the referent point of this as initially conceived was the state. By broadening the analysis to sectors other than the military, it is possible to examine other referent objects. While it is possible to mix levels, such that there are "local causes and global effects, or global causes and local effects", Buzan et al note that as in classical security complex theory, "the more important criterion is which actors are actually linked by their mutual security concerns" (Buzan et al 1998: 17-18).

This article seeks to advance this thinking by adapting the security complex theory to a collective of individuals. It is deliberate in targeting the level of individuals rather than the sub-unit level where prominent groups of individuals organised along identity or other dimensions such as armed groups, are able to influence the performance of the state. The interest in returning to this lowest level of analysis to attempt to make sense of and cumulate perspectives of peace and security held by individuals, is driven in part by the seeming disconnect in state - society engagement in much of Africa - discussed in the following section. Thus, the exploratory research presented in this article is an attempt to reflect on perspectives of security from below, the extent to which priorities and approaches to cumulating security differ from a top-down process and the lessons, if any, to be drawn from this. 


\subsection{Peacemaking and peacebuilding}

Given the continuing threat of violent conflict in Africa, the responses to conflict and the ways they are framed are critically important for finding sustainable peace. Much has been written on frameworks and approaches to conflict both normatively and in practice. Perhaps the entry point for all of this globally, is Boutros Ghali's Agenda for Peace (1992). Arguably, this effort by the UN to address a new class of conflict, that is, intra-state war that was unleashed as the Cold War came to a definitive end, occupies the intersection between theory and practice. And it is to this that we must return in trying to deal with the issue of how international response to armed conflict is framed.

The interrelated but sequentially presented notions of peacemaking, peacekeeping, peace enforcement, post-conflict peacebuilding, implied in Agenda for Peace has remained a haunting core of the UN's response to conflict. It has been difficult to reframe the approaches that the UN unveiled in the aftermath of Agenda for Peace and its Supplement (1995). Indeed in the report of the Panel on United Nations Peace Operations (United Nations 2000), commonly referred to as Brahimi Report, peacebuilding is defined as:

Activities undertaken on the far side of conflict, to reassemble the foundations of peace and provide tools for rebuilding on those foundations something that is more than just the absence of war ... effective peacebuilding is, in effect, a hybrid of political and development activities targeted at the sources of conflict (United Nations 2000: para. 44).

This focus on peacebuilding as something that takes place only in the aftermath of violent conflict and as something that entails a variety of political and developmental activities portrays peacebuilding as meaning everything to everyone.

An inordinate amount of attention has been focused on peacebuilding as a post-conflict activity. This is partly because of the conceptual and operational murkiness surrounding conflict terrains. Perhaps more significantly, UN Member States, not least those from the Global South were concerned that ideas of pre-conflict peacebuilding might be used as a pretext for intervention by more powerful states. However, the focus of UN peacebuilding on post-conflict contexts has become untenable. The range of consultations and meetings 
as well as field visits by the UN Advisory Group of Experts for the 2015 Review of the Peacebuilding Architecture (of which this author is a member) provided overwhelming evidence that peacebuilding is best seen as an activity that takes place throughout the whole of conflict cycle - in situations likely to lapse into violence, during high intensity conflicts and in post-conflict settings.

When viewed in this regard, the distinction between peacemaking and peacebuilding becomes artificial even if one could still conceive of peacekeeping as something that is a distinctively military undertaking which deserves it own framing. The challenge with separating peacemaking (as a diplomatic activity) and peacebuilding into another set of activities, which as suggested in the Brahimi Report occurs in the far side of conflict, is that the sequencing and fragmentation that characterises UN responses will continue abated. But when seen as a continuum, the efforts contained in the third party diplomatic activity of mediation and in the reconciliation of conflicting parties and related institution building can hardly be separated into distinct spheres.

This article therefore treats peacemaking as a continuum that encompasses the diplomatic efforts that produce peace deals, and the continuous facilitating of reconciliation and institution strengthening in the search for sustainable peace. The paper does not concern itself with the range of definitions and descriptions that have been ascribed to peacebuilding but takes all activities to build stable peace and reconcile war affected societies as parts of an overall peacemaking process.

\subsection{Approach to leadership in peacemaking}

In view of the challenge of conflict relapse, which has occupied global attention for some time, this article explores a particular dynamic in peacemaking processes - that of the approach to leadership. Peacemaking and related processes take a leader-centric approach, focusing on individuals in positions of authority rather than seek as a matter of course, a transformation in the relationship between those leaders and the populations they claim to represent. This focus on individual leaders reinforces a popular view of leadership but it is unhelpful for efforts to build stable peace in conflict-affected societies in Africa. It is the distinction between leadership perspectives that forms the focus of discussion here.

Leadership is an inherently complex construct. Several factors 
account for its complexity. First, leadership has no single universally accepted definition; there are as many definitions as there are interlocutors on the subject. Second, everybody engages in leadership as part of the practical reality of their world. Third, popular conceptions of leadership, which are narrowly focused and seem less complex, often capture people's imagination and therefore tend to influence perceptions and decision-making. Such popular notions, typically, frame leadership as an individual at the top of a hierarchy. This becomes all the more significant when people appear fixated on the personalities of such individuals who are considered great heroes, and therefore a panacea for all problems. Yet, when applied to the range of challenges discussed in this article, this leader-centric perspective is faulty at best or destructive at worst. As such, altering leadership perspectives within everyday society requires an element of imagination and innovation among other things.

Conceptually, separating individual leaders from the exercise of leadership while acknowledging their inter-connectedness is an important starting point. Although there is no universally accepted definition of leadership, there is a consensus on the broad perspectives that form the basis for leadership. Thus, the questions asked by analysts in the leadership studies literature, about the perspectives that we adopt in our analysis and practice of leadership, are worth returning to. Grint (2010) for example, asks four profound questions in his presentation of four alternative definitions of leadership, which help capture the complexity of leadership while focusing the mind on four perspectives from which to view leadership.

Leadership as position: is it where leaders operate that make them leaders?

Leadership as person: is it who the leaders are that make leaders?

Leadership as result: is it what leaders achieve that makes them leaders?

Leadership as process: is it how leaders get things done that makes them leaders? (Grint 2010: 4)

Typically, popular approaches deal with leadership largely from the first two perspectives. Position-based leadership places emphasis on those heading vertical hierarchies and arrogates power and responsibility to these people. (Grint 2010: 5) Person-based leadership focuses attention on the age-old traits approach, which gives pride of place to a lead- 
er's personality or character. As such, the notion of heroic or great leader is at the centre of this perspective to leadership (Pierce and Newstrom 2008). Northouse (2010: 5-6) refers to these two forms of leadership as assigned leadership and emergent leadership.

Thus, it is conceivable that particular persons occupying particular positions of authority are expected to provide solutions to critical challenges facing a population. The person and position perspectives might work in organisational settings particularly in business organisations or those designed for a range of single inter-related issues (including military and security organisations). But this approach has tended to yield little dividend in loosely structured or wider societal settings where problems are not just complex ones for which technical solutions can be found but wicked problems, which require extra-ordinary and adaptive responses (Grint 2010; Heifetz and Linsky 2002).

The critiques of some of these approaches to leadership, and the questions thrown up by the situations of conflict and insecurity, to which sustainable peace is being sought in Africa, invariably deemphasise some perspectives to leadership. For example, defining leadership as position or as person does not help explain the absence of stable peace in conflict-affected settings or societies even when there is a massive injection of local and international investment in peace. No matter how charismatic a person leading a group is, if solutions offered to competing demands do not effectively address the needs and aspiration of group members, conflict is not easily resolved.

In a wider societal context, the focus on a person-based leadership perspective is equally limiting particularly in conflict contexts. Either as a result of intervention fatigue or poor judgement, many peace processes give pride of place to the protagonists rather who do not readily seek mutual goals with the populations they preside over. The making of a peace agreement is often an important moment of opportunity for those intervening in conflict to alter the perspectives of protagonists toward building a common future with their people. Once this opportunity is missed it becomes difficult to bring citizens back to the attention of elites that are fixated on sharing the spoils of office.

Given the shortcomings observed in position- and person-based leadership, what promise do results-based and processed-based leadership perspectives offer for sustaining peace in conflict-affected societies? Results-based leadership might begin to move us in the direction in which the challenges to peace and security can be ad- 
dressed. The 'products' of leadership are an appropriate indicator of the degree to which the purpose of the exercise of leadership is realised (Grint 2010: 8). The purpose in question here is the prevention and management of conflict and realisation of stable peace in society. In this regard, a great deal of attention is placed on results such as early elections, truth and reconciliation programmes and economic recovery among other things. Interestingly, this raises two important questions. First, to whom (which leaders) are these results attributed? Second, even if we can link these results to specific leaders and their effectiveness - including people and organisations - how important is the process through which these results were achieved?

On the first question, unlike organisational settings in which results can be attributed to the chief executive or head of the organisation who is therefore rewarded for achieving those results, the situation is somewhat more complex in conflict settings. In such situations leadership of a peace process is ascribed to a named individual and an authorising institution. In many (but by no means in all) cases, these are actors from outside of the country where the conflict has occurred. As such, the UN, regional organisations, individual states can authorise peacemaking interventions in particular conflict situations. The results of those interventions are therefore attributable to these institutions and their representatives.

The experience of the past two and a half decades suggests that the methods of results-based leadership play an important role in determining leadership effectiveness in those interventions. The process through which the results of peace interventions were reached is just as important as the outcome. It is possible, for example, for results to be achieved through coercion or through unscrupulous or exclusionary means, which might invariably lead to a short-lived outcome. This is seen as a crucial factor in the derailing of peace processes and in the lapse or relapse into violent conflict. And it is this, which draws significant attention to process-based leadership as a potentially more effective perspective from which to pursue stable peace and to manage society's cumulated aspirations, particularly in situations where (democratic) institutions are weak or nascent.

Arguably, contexts of conflict are better understood and peacebuilding better enhanced by defining leadership as process. Studying the traits of a person, which distinguish them as a leader does not offer a sustainable way of defining leadership particularly in conflict situa- 
tions. Context matters in leadership and the importance of context cannot be overstated in this regard. In situations of conflict and insecurity, leadership does not reside in a person. Rather it is a function of an entire situation. As such, leaders invariably 'rise' and 'fall' as situations change not least because each situation demands certain types of actions and an individual may not consistently provide relevance across all situations (Murphy 1941). Defining leadership as process thus allows us to capture the dynamism of this construct in contexts of conflict and peacemaking, which are especially characterised by rapid change. And peacemaking, including peacebuilding, by its very nature - multi-dimensional and multifarious - exhibits similar dynamism.

To be effective in contexts of peace and security therefore, the focus of leadership must be on 'situations' as an entry point rather than individuals in positions of authority. In this regard, this paper aligns itself with Murphy's situational approach. Paraphrasing Murphy, Pierce and Newstrom (2008: 4) state:

... situations in which people find themselves create needs, and it is the nature of these demands that serves to define the type of leadership needed and thus who will lead ... Murphy views leadership as a function of the interaction between the person and the situation, where the situation consists of the follower(s) and the context confronting them.

Viewed from this perspective, the leadership process is an interplay between leaders and followers - a relationship between the situation, and the needs generated by that situation for the people and the individual(s) engaging in leadership in that situation (Pierce and Newstrom 2008: 4). Framed in this way, the dynamic nature of leadership and the pathway from leadership emergence to succession become apparent. This leadership process defines who the leader is and determines effectiveness of the group as a collective. It also determines the future needs of the group as well as who becomes the next leader of the group. Fiedler (1996) sees this process-based leadership as an on-going transactional activity between a person in a position of authority and the social environment.

Perhaps more significantly, process-based leadership is underlined by mutuality - the sense of common purpose - between person(s) engaging in leadership and the population to whom leadership is directed. It is difficult to achieve effectiveness in dealing with situations 
of conflict and insecurity when there is no common goal or mutuality between leaders and the population that they seek to lead. Arguably therefore, process-based leadership is crucial for responding to situations faced by groups in society, mediating differences and more importantly, in Africa, between society and the state from which it is largely alienated. This article places emphasis on process-based leadership in peacemaking processes as further discussed in section 4 .

\section{Individual perspectives on society's foundations of peace and security}

There is an inherent assumption in this article that human communities and their aspirations shape society. When cumulated, the expressed aspirations of individuals and groups of individuals offer some sense of a society's notion of peace and security. In turn, that society informs the nature of the state that emerges and the institutions that serve it. But at this present moment in Africa, the opposite tends to be the case. With few exceptions, African states are colonially inherited constructs and not the products of ideals and aspirations cumulated from the society below. As such, without a wholesale transformation of the institutions of governance, in many instances, the inheritance elite supplanted their colonial predecessors. Invariably, their ideas and the systems they preside over are superimposed on societies, whose realities are largely removed from the view of the state and the ruling elite.

Reflecting on Ekeh's work on colonialism and the two publics in Africa, one cannot help but see the continuing relevance of the public realms that he analysed so profoundly four decades ago. Ekeh described "two public realms in post-colonial Africa with different types of moral linkages to the private realm" (Ekeh 1975: 92). The primordial public, according to Ekeh, is "moral and operates on the same moral imperatives as the private realm" (Ekeh 1975: 92). The other public, the civic public, which is historically linked with colonial administration with its institutional hallmarks, that is, the armed forces, police and civil service - is best defined by its lack of moral linkage with the private realm and indeed the primordial public. Ekeh claims that "the civic public in Africa is amoral and lacks the generalised moral imperatives operative in the private realm and in the primordial public" (Ekeh 1975: 92). This indeed remains an apt reflection of the gulf that separates elite 
dominated formal systems from the daily realities of a large proportion of Africa's populations. Indeed, some of the conflicts that have plagued African countries are in part the result of struggles to reorder the relationship between the state and society (Olonisakin and Muteru 2014: 2)

Structures for the promotion of peace and security in Africa's post-colonial states, which have in turn been cumulated into regional security frameworks, are overwhelmingly state-led and state-focused. With few exceptions (including those mentioned earlier), they have rarely been the product of people- or citizen-led processes. Arguably therefore, there is a 'cart before horse' framing of peace and security considerations in Africa.

When this framing is inversed, it is possible to envisage human security cumulated from the perspectives of individuals. Peace, like security, represents a state of being in which people aspire to reach their full potential to 'live well' and 'live long'. This aspiration holds the promise of personal growth and development without a threat to people's presumed liberty to pursue these aspirations. The state of being for each individual in a society cumulatively defines that society's state of affairs from which the state subsequently draws its security and development vision. A society's security aspirations and agenda might seem aligned when viewed in a broad sense and in terms of articulated vision or principles. Arguably then, yearnings for security and peace occur at the personal level and then transcend to the state level, not vice versa. It underscores the notion that peace and security should be anchored on ordinary people's lived experiences. The protective umbrella of the state should ideally be provided across society through a cascading effect.

However, understanding peace and security from the perspective of individuals invariably reveals the inherently complex nature of these constructs not least in a region such as Africa, in which, many states are not the product of a cumulated expression of the collective will of citizens. Rather, they are a patchwork of abstracted ideals and structures handed down or gradually refined to suit post-colonial realities. The following case study illustrates individuals' notions and framing of peace and security and the potential challenges in cumulating them for society. 


\subsection{Case study}

This study involves a group of African youth participating in leadership programmes on peace and security at the African Leadership Centre in a classroom setting. It is a self-selecting group; each participant underwent a rigorous selection process for the leadership programme, which aims to build a next generation of African leaders and decision-makers on peace, security and development. This pre-selection stands them apart as a group of young African academics with a set of shared values, who are seeking to transform discourses on peace and security toward stable peace in Africa. As such, given their collective aspiration and their level of leadership consciousness, this group is assumed to constitute the makings of a 'peaceful community'. However, everyone on this 18-month programme originates from an African community with their own peculiarities and a keen sense of what creates insecurities for themselves and for their communities, some of which they aspire to change. The 30 participants in this study are citizens of six African countries including Cameroon, Ethiopia, Ghana, Kenya, Nigeria and Uganda. Each of the 30 participants in this study completed a questionnaire anonymously, after which they were constituted into focus groups for a follow-up open discussion about the issues contained in the questionnaire. The key objective of this case study was to understand participants' perceptions and experiences of (in)security.

The responses of these participants to the following six sets of questions in the questionnaire are relevant for the discussion in this paper:

- What does peace mean to you? Describe a time when you felt you were at peace.

- What makes you feel insecure? Describe a time you felt insecure.

- Do you want to live well? Describe what living well means for you.

- Do you want to live long? Describe what living long means for you.

- If you had to choose between living well and living long, which would you choose? Provide a reason for your response.

- Do you believe that living well and living long will bring you 
peace and security? Provide a reason for your response.

What emerged from this study is the complex debate that arises from a small-scale effort to cumulate the ideas and aspirations of a small number of presumed like-minded individuals. Below is a sample of responses to the above six sets of questions.

The following responses were provided to the questions: "What does peace mean to you? Describe a time when you felt you were at peace":

Respondent 1: "A state of mental wellness; being certain about where my life was heading".

Respondent 2: "Being protected from real or perceived danger; there is not a time that I have been at peace".

Respondent 3: "To be free and protected, to have the freedom of expression and opinion; I have not felt peace yet".

Respondent 4: "Living life without oppression; when I was a child and had less worries".

Respondent 5: "Not feeling threatened, loved ones safe and in good health; I have not yet felt peace".

Respondent 6: "Internal and external harmony; when I received my professional qualification, I felt at peace as my hard work was rewarded on merit".

Participants also had the following to say in response to the questions: "What makes you feel insecure? Describe a time you felt insecure":

Respondent 1: "The lack of physical security; walking down the streets of Nairobi at night".

Respondent 2: "The feeling of vulnerability because of the possibility of harm from a thousand sources; when my house was just robbed, I couldn't sleep well thereafter because of the fear of being robbed and raped".

Respondent 3: "Restrictions and too many laws and policing around me; I was holding a wedding planning meeting without police notification and was surrounded by police".

Respondent 4: "Injustice and war; during elections".

Respondent 5: "When things in my life get out of control; physical 
safety in 1998 and 2001, both periods of war and political instability, which led to my being a temporary refugee abroad".

Respondent 6: "Inability of leaders to improve living conditions in my country; when a school was attacked".

\section{The questions "do you want to live well? Describe what living} well means for you" elicited the following responses:

Respondent 1: "Yes; being able to meet my basic and secondary needs as well as my luxurious needs".

Respondent 2: "Yes; living in a secure place with no fear of danger or lack".

Respondent 3: "Yes; being healthy and having the power and means to do whatever I want".

Respondent 4: "Yes; being able to fulfil or accomplish my life goals and with benefits to others".

Respondent 5: "Yes; being healthy, being happy with one's choices, successful career, feeling fulfilled, surrounded by loved ones and family".

Respondent 6: "Yes; a comfortable life with freedom to live and make decisions, attain my full potential and be useful to society".

This sample of participants gave the following responses to the questions: "Do you want to live long? Describe what living long means for you":

Respondent 1: "Yes; it means living beyond my life expectancy of 60 years".

Respondent 2: "Yes, living and being healthy at the age of 95".

Respondent 3: "Yes, being healthy and having people around me who love me and support me".

Respondent 4: "Yes, living long to me is as long as I am active".

Respondent 5: "Yes, being able to pursue and fulfill my dreams".

Respondent 6: "Yes, being able to make a positive difference in people's lives so that I live long in their memories".

Participants in this study were asked: "if you had to choose between 


\section{living well and living long, which would you choose? Provide a} reason for your answer". Only one of the respondents in this sample chose living long and this response ratio reflected the pattern in the whole study. Only five respondents out of 30 preferred to live long if they had to choose. The respondents in our sample provided the following responses:

Respondent 1: "Living well; there is no need for me to live long if I can't be able to meet both my basic and secondary needs".

Respondent 2: "Living well; it is better to live a meaningful secured life than a long miserable life".

Respondent 3: "Living long; as long as I live I can work hard to have power and means to do what I want or like".

Respondent 4: "Living well; regardless of time, fulfiling purpose and adding value to people and society is more important to me".

Respondent 5: "Living well; better to live well than for many years suffering with no real purpose".

Respondent 6: "Living well; If I am able to live well, there is an increased probability that I will live long also, both literally and metaphorically".

Finally, the question on which respondents were split almost down the middle in their responses was this: "do you believe that living well and living long will bring you peace and security? Provide a reason for your answer".

Respondent 1: "Yes; in so far as living well is concerned, if I am able to meet my basic and secondary needs, I will be at peace mentally and be physically secure".

Respondent 2: "No; on second thought, living well and long cannot ultimately bring me peace and security because I exist in a community and without the security of that community, my security cannot be in isolation".

Respondent 3: "No; the two are contradictory forces; to achieve living well and long may involve unique approaches that could be characterised by greed, monopoly, etc".

Respondent 4: "Yes, because both will enhance human life and 
make it worth living. In order of priority, I will choose living well".

Respondent 5: "Not necessarily; one would hope that it would, and should endeavor to pursue that goal; yet external factors, which are beyond your control can't be accounted for".

Respondent 6: "Yes; for an individual, living well and living long will bring peace and security".

The respondents' statements as well as the focus group sessions that followed, reflect some of the ways people experience peace and (in) security. First, the momentary as well as elusive nature of peace is apparent in this sample and reflects the response pattern of the whole group. Second, the multi-dimensional experiences of insecurity are consistent with the notion of human security. Respondents' sources of insecurity range from threat to physical safety and consequences of war to absence of enhanced living conditions. Their sources of insecurity are not surprisingly, a reflection of the contexts in which they live.

In addition, several issues and challenges are highlighted by the responses. One is the complexity that surrounds efforts to cumulate the aspirations of individuals and groups into a coherent agenda. This study revealed that cumulating the aspirations of groups of individuals in society into a commonly agreed set of priorities is fraught with all sorts of dangers and are conflict-laden particularly in the absence of the moderating or mediating influence of institutions - which is often the case in many parts of Africa. Some of these dangers include gender, creed and age-based prejudices among others, which form the basis for conflict.

From the fairly homogenous group in this study - given their similar worldview and shared vision for Africa - it was still possible to note potential sources of conflict. When their expressions of 'living well' and 'living long' were further interrogated, it was possible to discern a potential for conflict. For example, the nuances in one respondent's idea of living well as being able to meet "luxurious needs", and another's as: "having the power and means to do whatever I want", were seen as potential sources of conflict. Unchecked power to achieve just any desired goal can potentially infringe on the opportunities of others who seek to pursue their own relatively modest aspirations. Similarly the discussion highlighted the role of priority setting and resource allocation. 
How, for example, might resources be prioritised for the care of members who live to the ripe old age of 95 years?

Perhaps the most revealing aspects of this study are the participants' perspectives on the question of whether living well and living long can bring about peace and security. At first glance, the even split in the "yes" and "no" responses would give the appearance that there are fundamental divisions on this issue. However, the division is not a real one. Discussions in the focus group sessions revealed that the overwhelming majority of respondents agree that living well and long can potentially provide the foundations for peace and security. Many of those who provided a "no" response did so on the basis of the danger of the 'unknown' in the external environment, which could potentially prevent the realisation of this aspiration. As one of the respondents aptly stated, "I exist in a community and without the security of that community, my security cannot be in isolation". This profound statement underscores the point that one is only as secure as those in one's neighbourhood. Thus, the need to build coherence into the security aspirations of people in the neighbourhood cannot be over-emphasised. As such, the idea of cumulating the aspirations of living well and long among diverse individuals and along communal lines is essentially about guaranteeing one's own security.

\subsection{Managing contradictions in the process of cumulating individual aspirations}

This thoughtfulness in the "no" responses draws attention to two important challenges in the effort to cumulate peace and security aspirations from below. First is that the groups and communities outside a particular group's immediate considerations might have radically different aspirations of living long and living well, which can potentially prevent this group from realising the collective aspiration of its members. Where such groups belong to the same principalities or political communities, the process of cumulating the aspirations of various groups upwards into a collective security vision would require residual capacity to mediate the differences in the aspirations of diverse groups. Second and perhaps more importantly, the nature of this capacity to mediate conflicting aspirations is crucially important to maintaining a peaceful, stable and secure society in which all of these groups' collective aspirations are pursued without degenerating into chaos. 
The ideal of cumulating all of society's aspirations of living well and long into a coherent national vision and agenda for peace and security therefore calls into question two crucial capacities. The first is the capacity to manage the contradictions in aspirations and the conflicting demands that arise from these contradictions. The negotiation of a common set of priorities is especially crucial for maintaining the stability and reproduction of a peaceful society in which to pursue individual aspirations. The complex interests in society invariably produce recognisable pockets of cumulated aspirations among seemingly likeminded groups as well as the dynamics that arise among groups as they pursue these aspirations. Inferring from Buzan et al's (1998) expanded security complex theory, one can locate miniature security complexes at this level in society. It is therefore possible to identify which groups are linked by their mutual (in)security concerns (Buzan, Waevar and de Wilde 1998: 17-18); and those groups that fall outside the commonly held goals. The capacity to negotiate this divide, thus preventing conflict by bringing such groups within a collective agenda, is key to maintaining a peaceful society.

The second capacity that is called into question concerns the management of a society's collective journey toward the pursuit of this national vision and agenda. This is the very essence of governance and politics and the umbrella provided by a state and its institutions so that the potential conflicts emanating from divergences in group aspirations and resulting competing demands can be effectively managed. As Zartman aptly reflects, "politics is the process of handling demands, and demands unhandled can escalate from politics to violence" (Zartman 1991: 300).

Ideally, the African state ought to have evolved from society's aspirations. But given the trajectory of most African states, there is a fraught process of bridging the gap between colonially inherited governance systems and African societies. As such, in many cases, Africa's ruling elite and the state institutions over which they preside, seem far removed from ordinary people and their aspirations. In effect, Ekeh's analysis of the "two publics" and their relationship with the private realm remains relevant to this discussion. Indeed the absence of mutually held goals between leaders of the state and wider society accounts in part for the persistence of violent conflicts in Africa. The essence of the state and its institutions is precisely to manage and mediate the contradictions and conflict within society, which result in part from conflict over 
the means to pursue individual ambitions of living well and long.

\section{Leadership's undergirding role in managing society's contradictions and competing demands}

In the absence of the moderating and mediating influence of the state and its institutions, leadership becomes an even more crucial factor in the process of cumulating individual aspirations and negotiating societal priorities. However, there is a potential tension between leadership and the institution-focused approach to problem solving in the area of peace and security. Across developing societies, including in particular, those afflicted by high levels of insecurity, research and policy have tended to focus on the weakness of (democratic) institutions. It is taken for granted that strong and effective institutions will regulate political and administrative behaviour in such contexts. As such an overwhelming amount of attention is focused on institution building.

While the assumption that a strong institution will promote effective leaders is not flawed in itself, experience across African societies suggests that this is not the natural order of things. In the absence of strong and effective institutions - a major challenge for the management and prevention of violent conflict - leadership offers perhaps the only viable entry point for the building of agreed core values and systems that will in turn produce such institutions. Indeed, this among other factors leads Rotberg to claim that "governance in sub-Saharan Africa is much more dependent upon qualities of leaders and leadership than it is in other places" (Rotberg 2007: 17).

Even if there were agreement that leadership is a crucial starting point for the transformation of peace and security in Africa, the potential for success depends very much on the perspective of leadership that is brought to bear. If leadership is to make a positive difference to the context in which challenges to peace and security such as the conflicts and insecurities that persist in Africa are to be addressed, the perspective from which leadership is applied is of particular importance. Process-based leadership is crucial in this regard. 


\subsection{How does process-based leadership enhance peacemaking and human security?}

Peace and [human] security, like process-based leadership are relational; and they are held together by mutuality. The sense of common purpose, which connects those whose security concerns are mutually linked, is inherent in process-based leadership. When assessed from a leadership perspective, conflict contexts in Africa reveal important leadership dynamics, which serve both as causal and sustaining factors for conflict and human insecurity. In the last two decades many conflict situations in Africa have been underlined by a narrow self or group interest approach to leadership. Rarely are there mutually held goals between national leaders and the populations or societies that they govern. In conflicts in the Central African Republic, and South Sudan after the referendum, for example, it has been difficult, to find a sense of shared destiny between the leaders of the state and a broad segment of the population beyond their narrow groups.

Furthermore, leadership is easily forged in locales outside of the state and as such, there exists a range of alternative centres of power over which the state has no control. All of this serves to create a significant degree of weakness for the state since non-state institutions tend to be better able to purchase the loyalty of citizens - without systematic linkage and interaction with state institutions. Therefore, realising the goal of stable peace in conflict affected states in Africa depends largely on the willingness and ability of the leaders of the state to build state institutions that are underpinned by a shared national vision between them and the populations that they govern. This requires altering leadership perspectives from that of person or position, which presently dominates peace agendas.

There are three important leadership questions raised for any effort to find solutions to transform the current conflict terrain for peace and human security. First, how can the activities of peacemakers and interveners not least UN and regional actors, be directed to help leaders and their people forge mutual goals and common pursuit of their collective future? Second, how can elite-bound arrangements be redirected toward a common vision of peace and development for leaders and the whole of society? Third, what can be done to alter the behaviour of Africa's governing elite away from self-serving goals and 
toward the path of mutuality between them and the populations that they govern?

\subsection{Lessons from peacemaking in Africa}

Leadership features either subtly or prominently in virtually all attempts to make peace. But beyond a narrow, albeit popular perspective, it is often not a subject that receives extensive interrogation among analysts and peacemakers alike. It is almost always a forgone conclusion that peace processes would encompass leadership because at the core of these efforts are leaders that are being reconciled. This leadercentric approach makes it virtually impossible to explore leadership from another perspective in the course of peacemaking in African conflicts.

Thus, in a wide range of conflict situations in Africa, peacemaking tends to adopt a perspective to leadership, which works against societal conditions for peace and reinforces the classical peacebuilding dilemma, that is, the relapse into armed conflict. In particular, the model of peace that is advanced focuses less on the human security issues that lie at the root of many African intra-state conflicts. Yet, the foundations of peace and conflict are shaped by particular leadership as well as human security perspectives, which are in large part, not at the core of peacemakers' considerations.

A cursory look at the responses to situations of violent conflict and insecurity in Africa might give the impression that process-based leadership is already occurring. It could be argued, for example, that by imposing particular models of peacebuilding on those conflict situations, process-based leadership is being employed. Post-conflict electoral processes, for example, might be seen as an effort to build mutuality between leaders and people. However, critiques have argued that the overwhelming focus is on building consensus among feuding elites who are often at the centre of conflict, rather than between these elite groupings and the larger society, which continues to linger in insecurity. In the vast majority of cases, the underlying issues that kept populations and leaders divided remain unaddressed and conflicts potentially mutate into other forms. We have therefore witnessed many situations of negative peace rather than positive and sustainable peace. Below is a snapshot of the models of peace adapted to several African contexts, the resulting circumstances and how an alternative leadership per- 
spective might have shaped a different outcome.

Peace agreements are one indicator of the model of peace adopted in African conflict situations, for example, civil wars. In the past two decades, with the few exceptions of situations where conflicts ended on the battlefield with a clear victory for one party and defeat for the other (Ethiopia, Rwanda), peace agreements have exhibited similar features. This model of peacemaking reinforces a popular, personbased approach to leadership; it is an unhelpful even if logical approach to peacemaking in these contexts. The peace agreements in a number of prominent armed conflicts in Africa in the last two and a half decades have evolved a classical model. This includes, for example, the negotiated settlements in Liberia, Sierra Leone, Cote d'Ivoire, DRC and the Comprehensive Peace Agreement on South Sudan, which is a slight variation of these given the unique circumstances in which the South Sudan was seeking a separation from Sudan.

A first feature of these agreements is that they are leader-centred rather than leadership-focused. The need to get the war-leaders to agree on a non-violent pursuit of conflict is the overriding aim of peacemakers. In Liberia, Sierra-Leone and Cote d'Ivoire, for example, those who bore arms were the dominant concern of the peace agreements. Liberia provides perhaps the most notorious example in which warring parties splintered on several occasions, reneging on an agreed peace and then returning to the battlefield in order to stake a place at the peace table. In Liberia's first war which lasted from December 1989 to the signing of the Abuja /I Peace Agreement in August 1996, what started as a two-party conflict between Charles Taylor's National Patriotic Front of Liberia (NPFL) and the government of Samuel Doe ended with an agreement between eight warring factions. The second war, which began in 1999 ended with the signing of a Comprehensive Peace Agreement (CPA) in 2003, bringing the peace agreements signed in Liberia since 1990 to a total of 14.

A second feature of the peace agreements is their institutionbuilding focus. A number of institutions and programmes have become a common feature of peace agreements although each situation has the odd variant. These include, for example, independent commissions on elections; truth and reconciliation commissions; disarmament, demobilisation and reintegration programmes; and security sector reform programmes among others. In the case of Sierra Leone, a Commission for the Consolidation of Peace and Strategic Mineral Resource Man- 
agement Commission were part of the structures created under the Lome Peace Accord.

In virtually all situations where these peace arrangements exist, some of the structures created for peace become the channel through which power is shared between the protagonists. In Sierra Leone following the Lome Peace Accord of July 1999, Foday Sankoh, leader of the Revolutionary United Front (RUF) became Vice President as well as Chair of the Strategic Mineral Resources Commission. As one observer noted, "it was like asking a hyena to guard a slaughterhouse" (Olonisakin 2008: 39). Johnny Paul Koroma, former army commander who colluded with the RUF to oust President Kabah in the May 1997 coup was rewarded with headship of the Commission for the Consolidation of Peace. Similarly in Liberia, key leaders of the rebel factions - Liberians United for Reconstruction and Democracy (LURD) and Movement for Democracy in Liberia (MODEL) - occupied prominent positions in the transitional government that was established as part of the CPA in 2003. Joe Wylie, for example, was Deputy Minister for Defence while Kabineh Janneh was Minister for Justice.

Invariably, so much attention is focused on the politics of feuding elites as well as the technicalities of bringing all the elements of peace agreements together, that the significant task of reconciling the larger society is relegated to the background. An institution building focus of this nature places limited emphasis on genuine societal reconciliation. Deep reconciliation particularly in societies that have been torn apart by long term conflict requires sustained attention to conflict transformation. The overwhelming focus of peace efforts on the protagonists or individuals who bear arms, shifts attention away from the rest of society. As such, there is often no basis or space for societal 'conversations' about the deep-seated causes of the conflict and the collective aspirations for building a harmonious nation. Without a leadership perspective, which seeks to forge a sense of common purpose between protagonists in war and the broader society, the UN, regional actors and those responding to conflict risk continuing the cycle of conflict.

Third and related to the second, early elections are a feature of the peace agreements. In this regard, early elections are an important marker of a peaceful end to conflict. However, empirical evidence points to conflict relapse in most of the cases where this model of peace has been applied. The focus on early elections following a peace deal legitimises the same war leaders and invariably seals the fate of citizens 
who have had limited opportunity to participate in shaping the future. The window of opportunity to make demands on these leaders closes swiftly once a peace deal is cemented through early elections. Peacemakers invariably return to the sites of such flaky peace to rescue populations from the consequences of recurrent violence. In several cases, the overwhelming focus on leader and person-based approaches to peacemaking caused peace to fail.

Some examples are worth highlighting in this regard. Despite the relief that greeted the signing of the ECOWAS-negotiated Abuja Supplementary Agreement on Liberia in 1996 and Taylor's subsequent landslide victory in the 1997 elections, there was a return to armed conflict in 1999. In Sierra Leone, following the 1999 Lome Peace Accord that gave Foday Sankoh a prominent place in post-conflict governance arrangements along with blanket amnesty, Foday Sankoh and the RUF created chaos in April 2000 in Freetown - a situation, which resulted in Sakoh's eventual arrest in May of the same year (Olonisakin 2008).

More recently in South Sudan, an overwhelming amount of attention was focused on the key protagonists and war leaders - first John Garang, then Salvir Kirr and Riek Machar. A hard won Comprehensive Peace Agreement resulted in a referendum and eventual separation of South Sudan from Sudan in 2011. A new state emerged and the relative peace unravelled in 2013 with Salva Kirr and Riek Machar taking the new country back to the path of war. Perhaps more importantly, in this case, the focus of the UN mandate (UN Resolution 1996, 2011) until the outbreak of conflict in South Sudan in 2013 was on the technical elements of capacity building. Limited focus was given to reorienting the attention of South Sudan's leaders toward comprehensive relationship building with the whole of South Sudanese society to evolve a common national vision. ${ }^{3)}$

The question that arises then is what formula for peace could have replaced this classical approach? The exchange of influence established between the peacemakers and war leaders in the first instance - itself an example of process-based leadership - should have been converted or transferred to an exchange of influence between those leaders and their societies. For example, ceasefire agreements, followed by comprehensive peace plans that include a long process of priority setting and a series of referenda that involve the entire society casting their ballot for national priorities and revenue allocation before having to vote to select particular leaders, is an option that is yet to be 
tried and tested. Such an option will most certainly be allergic to checklists and short timeframes. Acceptance of such a formula as a key part of a peace processes is worth pursuing in the search for stable peace.

Evidence from these countries indicates that allowing feuding parties to take over the reins of power without securing a more inclusive peace agenda produces costly peace. This requires a longer-term and demands staying power from interveners. It is the least that can be done to secure and sustain peace.

\section{Conclusion}

Conflict relapse remains a continuing challenge without evidence of a workable formula for sustaining peace in Africa. Under these circumstances, the case for an alternative perspective to peace, security and leadership is worth exploring. This has implications for peacemaking approaches of regional, continental and global actors let alone national actors that have typically deployed other methods toward resolving their conflict. The contribution of Buzan and others to the wider security agenda provides a basis for examining the security aspirations of people in African societies. The relevance of the 'security complex theory' to the level of the individual and wider society is rarely explored. A closer look reveals that just like states, individuals and groups of individuals are linked by their mutual aspirations, which can be cumulated upwards in ways that reflect a societal vision of peace and security.

The case study presented in this article illustrates how the aspirations at the level of the individual reflect the diversity of issues expressed in the human security paradigm. The efforts to cumulate the interests of this collective of individuals reveals a situation and processbased approach to negotiating contradictions and competing interests. Discussions and decisions about the group's collective priorities were based on issues such as resources and timeframe and not on any one individual's preferences. This supports the argument for a processbased approach to leadership. Arguably, failure to cumulate security priorities of members of society into a collective national vision is one of the issues at the core of conflict. Additionally, evidence from conflict situations at higher levels in society suggests that cumulated perspectives from below and a process-based approach are not at the core of responses to conflict. 
Leadership is an important 'driving force' shaping the aspirations of groups of individuals in society and in relations between society and the state in Africa. Strong inclinations by global and regional actors for institution building without sequencing process-based leadership as an entry point poses a key challenge to peacemaking. There is a dilemma in which peacemakers are caught between the imperative to deal with armed conflicting parties just to stop the violence or to prioritise the human security aspirations of the people. Many a peacemaker would therefore argue that the essence of focusing on the former is to secure the latter. But the inordinate attention to the demands of war leaders invariably locks the society into a cycle of conflict.

The research presented in this article is exploratory. In the emerging thinking that peacemaking is among other things about "leadership building", the aspirations of individuals seeking to reach their full potential cannot be excluded from the search for stable peace. This idea of leadership building in processes that bind people and their leaders to pursue a collective destiny is a subject that requires further research.

\section{Endnotes}

1. The articles by Hendricks; Murambadoro and Wielenga; Ababu Kifle; and Okech in Strategic Review for Southern Africa, Vol 37, No 1, draw attention to these diverse, multi-level conflict situations.

2. Organisation of African Unity (OAU) was in existence from 1963 until 2001 when the Constitutive Act of the African Union entered into force.

3. The failure of South Sudanese leaders as well as their international allies to seek a future that included the whole of South Sudanese society was one of the dominant views among key interlocutors during this author's field visit to South Sudan from 26 April to 8 May 2015.

\section{Bibliography}

African Union (2000), The Constitutive Act of African Union, Lome, Togo, 11July.

Boutros-Ghali, B (1992), An Agenda for Peace: preventive diplomacy, peacemaking and peace-keeping (A/47/277-S/24111). New York: United Nations, 17 June.

Buzan, B, Waever, O and J De Wilde (1998), Security: A New Framework for Analysis. Boulder, CO and London: Lynne Rienner.

ECOWAS (1993), Revised Treaty of the Economic Community of West African 
States, Volume 2373, 1-42835, 24 July.

ECOWAS (1996), Supplement to the Abuja Accord, 17 August.

Ekeh, P (1975), "Colonialism and the Two Publics in Africa: A Theoretical Statement", Comparative Studies in Society and History, Vol 17, Issue 1, pp 91112.

Fiedler, E F (1996), "Research on Leadership Selection and Training: One View on the Future", Administrative Science Quarterly, No 41, pp 241-251.

Galtung, J (1964), "An Editorial", Journal of Peace Research, 1964, Vol 1, No 1.

Galtung, J (1969), "Violence, Peace and Peace Research", Journal of Peace Research, Vol 6, No 3, pp 167-191.

Grint, K (2010), Leadership: A Very Short Introduction, Oxford: Oxford University Press.

Heifetz, R A and M Linsky (2002), Leadership on the Line: Staying Alive through the Dangers of Leading, Boston MA: Harvard Business School Press.

Lacina, B and N P Gleditsch (2005), "Monitoring Trends in Global Combat: A New Dataset of Battle Deaths", European Journal of Population, No 21, pp 145166.

Murphy, A J (1941), "A Study of the Leadership Process", American Sociological Review, Vol 6, pp 674-687, Reprinted in Pierce, J L and J W Newstrom (2008), Leaders and the Leadership Process: Readings, self-Assessments and Applications. New York: McGraw-Hill and Irwin.

Northouse, P G (2010), Leadership: Theory and Practice, Los Angeles: Sage.

Olonisakin, F (2008), Peacekeeping in Sierra Leone: The Story of UNAMSIL, Boulder, $\mathrm{CO}$ and London: Lynne Reinner.

Olonisakin, F (2009), "ECOWAS and Civil Society Movements in West Africa", Special Issue, Security and Development in an Unequal World, IDS Bulletin, March.

Olonisakin, F and A Muteru (2014), "Reframing Narratives of Peacebuilding and Statebuilding in Africa", ALC Working Paper, No 16, February.

Paris, R (2001), "Human Security: Paradigm Shift or Hot Air", International Security, Vol 26, No 2.

Peace Agreement between the Government of Sierra Leone and the Revolutionary United Front (RUF/SL), 7 July 1999.

Pierce, J L and J W Newstrom (2008), "On the meaning of Leadership", in Pierce, J L and J W Newstrom, Leaders and the Leadership Process: Readings, SelfAssessments and Applications. New York: McGraw-Hill and Irwin.

Rotberg, R I (2007), Governance and Leadership in Africa. Broomall PA: Mason Crest Publishers.

United Nations (1996), Security Council Resolution 1996 (South Sudan), S/RES 1996. 
United Nations (2000), Report of the Panel on United Nations Peace Operations, UN Doc. A/55/305-S/2000/809.

Zartman, I W (1991), "Conflict Reduction: Prevention, Management and Resolution", in Deng, F M and I W Zartman (eds), Conflict Resolution in Africa. Washington DC: The Brookings Institution. 